\title{
Kleinschalig onderwijs en schaalvergroting
}

We hebben een probleem in het medisch onderwijs anno 2001. Enerzijds is de vraag naar artsen groot, omdat er een stijgend tekort is aan huisartsen en medisch specialisten. Anderzijds kunnen de faculteiten niet, met behoud van kwaliteit, veel meer toekomstige artsen opleiden. Een van de redenen is dat de meeste medische faculteiten deels zijn overgeschakeld op interactief en kleinschalig onderwijs. Trainen van vaardigheden en leren oplossen van medische problemen in de toenemende kennisjungle zijn domeinen die zich niet lenen voor grootschalig onderwijs. Medische beroepen zijn praktisch en expertise erin komt pas door veel oefenen en reflecteren tot stand. Dit geldt overigens zowel voor de basisals voor de vervolgopleidingen.

De medische basisopleiding en de vervolgopleidingen zijn een lange pijpleiding voor jonge mensen die een medisch beroep kiezen. De opleiding van een huisarts duurt thans minimaal negen jaar, die van een specialist langer dan elf jaar. De overgrote meerderheid van de studenten wordt uiteindelijk huisarts, perifeer werkzaam medisch specialist of sociaal geneeskundige, drie duidelijk van elkaar verschillende beroepen. En toch besteden wij een ruime helft van het opleidingstraject aan het opleiden van uniforme basisartsen en gaan wij ervan uit dat zij omniblasten moeten zijn, die allemaal dezelfde problemen kunnen aanpakken als zij afstuderen. Maar de problemen die zij in hun latere beroepspraktijk zullen tegenkomen en nog belangrijker - de aanpak van die problemen zijn totaal verschillend.
Ik vind dat een maatschappelijke realiteit - in dit geval het tekort aan artsen - de duur en de vorm van de medische opleiding mede dient te bepalen. De keuze omniblasten op te leiden kost veel tijd, inspanning en geld, en is volgens mij niet erg efficiënt. Zou het niet meer voor de hand liggen om eerder met het vervolgtraject te beginnen? Er wordt al gefluisterd dat het gemeenschappelijke deel, de echte 'core' dus, ongeveer vier jaar kan duren. Tijdens die periode wordt de echte basisarts gevormd. Daarna kan de opleiding volgen die toegang geeft tot een medisch beroep. De opleidingen zijn een leer-werkperiode, waarbij de student al werkzaam is in de gezondheidszorg. Voor de discipline huisartsgeneeskunde lijkt mij een periode van drie jaar ruim voldoende. Naast de werkzaamheden kan er kleinschalig onderwijs gegeven worden toegespitst op de beroepsuitoefening. Zo leren de studenten sneller de aanpak die eigen is aan de beroepsgroep.

Tot op heden, en dat is een belangrijke hinderpaal voor een dergelijke nieuwe aanpak, zijn de beroepsgroepen en de faculteiten niet met elkaar in overleg over onderwijs. Mijns inziens biedt een eerdere differentiatie of een verkorting van de basisartsopleiding en daardoor een verkorting van het totale traject mogelijkheden om met behoud van kwaliteit meer artsen op te leiden.

Verder moet er goed gekeken worden wat andere Europese landen voor plannen hebben en hoe de wetgeving aangepast moet worden.

Roy Remmen 